\title{
Fairy Tales and Their Contribution to the Process of Constructing Gender Roles
}

\author{
Zeynep Özge Iğdır ${ }^{1}$
}

\begin{abstract}
As it is widely known that fairy tale reflects the basic characteristics of a culture. Beside their functions such as preparing children for sleeping, to improve their imaginary, and guiding for the appropriate attitudes and behaviors; they have a critical role in the process of transferring basic rules and norms of the society to the next generations. In this paper, I would like to propose a study examining how fairy tales contribute to the process of constructing and transferring gender roles. More specifically, this proposed question aims to investigate the decisiveness of narrators of the fairy tales in the process of transferring gender roles. This question is worth studying and needs scientific attention since the survival of the fairy tale depends on social acceptance. In other words fairy tales are needed to be reproduced according to the needs of the society in that specific period. Additionally, examining reproduction process is critical to understand how gender roles are constructed and transferred. The hypotheses of this study examine decisiveness of women as the narrators of the fairy tales in the process of transferring gender roles.
\end{abstract}

Keywords: Gender, Fairy tales, Narrator

\section{Masallar ve Toplumsal Cinsiyet Rolleri Oluşturma Sürecine Katkıları}

\begin{abstract}
$\ddot{O} z$
Masalların bir kültürün karakteristik özelliklerini yansıttıkları yaygın olarak bilinmektedir. Masallar, çocukları uykuya hazırlama, onların hayal güçlerini geliştirme ve toplumsal olarak kabul gören tutum ve davranışlar konusunda rehberlik etme işlevlerinin yanı sıra temel toplumsal kural ve normların gelecek nesillere aktarlması sürecinde de kritik bir rol oynamaktadır. Bu çalışmada, masalların toplumsal cinsiyet rollerinin oluşturulması ve aktarlması süreçlerine nasıl katkıda bulunduklarını inceleyen bir araştırma ortaya koymaya çalışlyorum. Daha spesifik olarak, ortaya koyduğum bu soru toplumsal cinsiyet rollerinin aktarılması sürecinde masal anlatıcılarının belirleyiciliğini inceleme amacını taşımaktadır. Masalların hayatta kalmaları toplumsal olarak kabul görmelerine bağll olduğundan bu soru bilimsel ilgiyi gerektirmekte ve araştırılmayı hak etmektedir. Diğer bir deyişle masalların belirli bir dönem içinde yeniden üretilmeleri gerekmektedir. Ayrıca bu yeniden üretim sürecini incelemek, toplumsal cinsiyet rollerinin oluşturulması ve aktarılmasını anlamak açısından kritik bir önem taşımaktadır. Bu çalışmanın hipotezleri, masal anlatıcıları olarak kadınların toplumsal cinsiyet rollerinin aktarllması sürecindeki belirleyiciliklerini incelemektedir.
\end{abstract}

Anahtar Sözcükler: Toplumsal cinsiyet, Masallar, Masal anlatıcısı

1 Boğaziçi University, Department of Politics and International Relations, MA student, Email: zeynep.igdir@boun.edu.tr 


\section{Introduction}

As it is widely known that fairy tale reflects the basic characteristics of a culture. Beside their functions such as preparing children for sleeping, to improve their imaginary, and guiding for the appropriate attitudes and behaviors; they have a critical role in the process of transferring basic rules and norms of the society to the next generations. Thus, in this paper, I would like to propose a study examining how fairy tales contribute to the process of constructing gender roles in the society. More specifically, this proposed question aims to investigate the decisiveness of narrators of the fairy tales in the process of transferring gender roles. This question is worth studying and needs scientific attention since the survival of the fairy tale depends on social acceptance. In other words they are needed to reproduce according to the needs of the society in that specific period. Additionally, examining that reproduction process is critical to understand how gender roles are constructed and transferred.

Therefore this paper includes five sections: a brief of the literature review, methodology of the research, findings and finally conclusion and suggestions for further studies.

\section{Literature Review}

This section of the paper covers the literature about the theme of this study. To consider the question of the research I need to define some terms. Thus firstly, I will define the terms of literature, fairy tale, gender, genre, and narrator; secondly, I will discuss the social function and the morphology of the fairy tales and finally, I will take up the literature on the relation between gender and fairy tales.

First of all, within the existing literature, gender is defined as "[the] way of seeing and representing people and situations based on sex differences which is also a social or cultural category influenced by stereotypes about 'male' or 'female' behavior and exist our attitudes and beliefs. Such beliefs are said to be culturally produced and constructed" (Goodman, 1996, s.8). Genre is defined as "a key term used to distinguish between distinct types of writing (or art, or thought)" (Goodman, 1996, s.8). Here, it refers one of the major forms of literature: fairy tale. Fairy tale is defined as "the discipline of imagination" (My translation, Sezer, 2010, s.11). It is indicated that fairy tale as a genre of literature did not emerge for children at the first time instead, it is derived within an oral story telling tradition and created by adults; they were accepted firstly among adults and in the 18th century spread to children (Zipes, 2006, s.3). Zipes also points out that they have a function to humanize and stabilize some forces which cause conflicts both in people minds and in society (1999, s.1) Class and gender phenomena in those fairy tales are also mentioned by stressing that they provide the hegemonic interest of males within the upper classes of particular societies and communities (Zipes, 1999, s.7). Thus we can say that one of the functions of the fairy tales for children is to teach the basic codes of the society which includes both gender roles and class issues.

Additionally, İvgin also states that fairy tales have more than one version which is available for children and non-literates (1988, s.57). Story telling is defined as "the outcome of an instinct implanted universally in the human mind" (Hartland, 2011, s.1). It is also indicated that the genre of fairy tale firstly emerged from this tradition and they were published. Narrator refers to story teller and plays a very critical role since it includes imagination and interpretation which are considered as the central to the discussion of gender and literature in more specific sense (Goodman, 1996). It is not possible to think on narration without ideology because "ideology is formulated by and in language, meanings within language are socially determined, and narratives are constructed 
out of language" (Stephen, 1999; cf. Jarrar, 2009, s.35). Thus it is not possible to understand fairy tales without examining story teller. In addition retelling of the stories plays a significant role in the reproduction of the all values, ideologies, cultural codes, beliefs embedded in fairy tale. The retelling per se has a voice which reminds those cultural codes to the adult while teaching to children. According to Lieberman, fairy tale retelling provides connection with pre-text and make aware of the readers about the possible issues and interpretations which they may have not noticed before (Lieberman, 1972; cf. Joosen, 2011, s.55). These re tellers are generally women (My translation, Boratav, 1995, s.84). Başgöz mentioned that every narrator recreates the story with regard to the area around him/ her thus every tale is a variation and all variations are recreations (My translation, Başgöz, 1988, s.26). In addition narrator can change some parts of the story and these changes are not limited with the pattern such as language and telling features but also compromises structure of the story, drawings of the characters, ideology and function of the story (Başgöz, 1988, s.26). Narrator does not avoid remarking his/ her negative opinions on characters, events, situations and tend to embed the events into immediate surroundings or tend to tell the story as he/ she passed through (My translation, Boratav, 1992, s.36). In other words, story teller may instill the minds of children ideological messages that socialize them to meet normative expectations of mainstream culture (Jarrar, 2009, s.35).

Furthermore, because of the social and cultural character of gender which the paper has already mentioned, the study of literature and gender refers not to analyze literature with regard to the sex or sexuality of authors rather a kind of literary analysis as they are written, read and interpreted within cultures both by women and men (Goodman, 1996, s.7). Additionally, fairy tales emerged from storytelling tradition as folk tales. Here we must mention that because the further levels of the study include in depth interviews with ordinary people, to avoid the possible problems about the knowledge of the interviewee's on these two genres (it can be confusing to differentiate one to another), the paper does not take the variations of tale forms into consideration.

Secondly, this study takes one of the most important Russian folklorists, Vladimir Propp's morphology as a frame to approach fairy tales. Propp sees literature and folklore as class phenomenon and defines folklore as"the literary output of the exploited classes" (1984, s.40). For him, who manifested himself as a Marxist, from the historical perspective, the entire creative output of the humanity is folklore. Propp's morphology which examines the structure of the tales refers thirty one elements that are always the same and always follow one another in the same order and finally, that only characters should be taken into consideration (Propp, 1984, s.7). In addition Propp stresses the importance of the function of the characters which is always the same (2008). Although Propp firstly examined the Russian folk tales, some other scholars indicated that other nations' tales are also applicable to these functions because of the similarity of the functions of the characters (Taner, 1988, s.163).

Thirdly, it is widely argued that "fairy tales have socializing power which teaches values, beliefs, and behavioral patterns to children (and also to adult) and what they read is believed to have a substantial influence on the construction of their own identity, on their beliefs and expectations toward others, and their conscious and unconscious associations" (Lieberman, 1972; cf. Joosen, 2011, s.92). In addition, Bettelhem also remarks the impact of fairy tales on both unconscious and conscious levels. He stresses deeper psychological processes in which children built a empathic 
relation with the protagonist of the tale that is resulted in "self- realization at the end and this model of identification onto both the child's conscious and unconscious and offer meaning on so many different levels" (Bettelhem, 1976; Joosen, 2011, s.125). Therefore we can conclude that gender roles are constructed -not only of course- through fairy tales within an endless process.

Fairy tales also provide the reproduction of gendering through the relationship between mothers and their daughters. It is claimed that "the function of the intrinsic relationship of femininity and motherhood in the development of female is very critical regardless of whether or not she becomes a mother herself" (Wilkinson, 2008, s.7). Therefore women as the product of mothers affect other women. Additionally "women as mothers are pivotal actors in the process of social production and responsible for the reproduction of masculinity and sexual inequality, and of the reproduction of particular forms of power" (Chodorow, 1978; Wilkinson, 2008, s.7).

The similarity of representation of women in fairy tales in different cultures can be easily observed. Yavuz claims that "studies on fairy tales show that these stereotypes do not change one culture to another" (1997, s.55). Good women are generally represented as altruist, naive, content and passive while bad ones are represented as being dependent, ambitious, violence prone and evil. Additionally, beauty of good women is always taken into account as the ugliness of the evil ones. Good women are nearly always in trouble and they need to be saved. If they do not resist the life that they are forced to obey, they will be awarded with a happy marriage. This marriage never happens with someone from lower class. Therefore obedience gives "the promise of upper class" to women (My translation, Sezer, 2010, s.131). Similarly relatively dependent ones are represented as being evil in the fairy tales. These women are generally witches, step mothers, magicians. Furthermore there is always a vocation in the fairy tales which represents "pubescence of the protagonist" (Sezer, 2010, s.33). For women this vocation starts with "leaving home in which the source of power is fathers and ends in another home (or kind of palace, castle) in which the source of power is husbands at this time" (My translation, Sezer, 2010, s.37). In other words, vocations of women refer to the transition of the source of power which they obey.

To sum up, the existing literature shows that there is a strong relationship between fairy tales and construction of gender. Values, beliefs behavioral patterns, cultural codes are transferred to next generations through fairy tales. Narrator plays a very critical role in the reproduction of the mainstream social codes and these narrators are generally women. Thus women as the product of other women are the main actors in the process of reproduction of gender roles. Although the literature points out that the form of this relationship does not change too much culture to culture, most of the analysis which examines the relationship between gender and fairy tale (lets say literature) focus on Western literature and folklore. Therefore studies which examine Non-Western fairy tale traditions can fill this gap and provide a wider overview how gender is constructed and reconstructed through fairy tales.

\section{Methodology of the Research}

In the research the main concepts I want to examine are gender, fairy tale, narrator which were defined above. The hypotheses which this study will test examine the decisiveness of women as the narrators of the fairy tales in the process of transferring gender roles. Thus my hypotheses are:

- Fairy tales are one of the sources of transferring gender roles. 
- The narrators of the fairy tales are decisive in the process of transferring gender roles.

- The narrators of the fairy tales are mostly women.

- Gender roles are transferred by mothers to their children through fairy tales (not only but also).

In addition, I started to the research on the December of 2012 and finished at the end of the month. I used qualitative research methods for gathering the data, since the aim was to uncover the contribution of fairy tales in the process of constructing gender roles. Because the importance of the narrators in this process I conducted in depth interviews with only women as the narrators of the fairy tales. Because I wanted to see how women as mothers are decisive in the process of transferring gender roles, I interviewed with only women. This study required to interview with both ordinary women and also specialists. In the first place, I interviewed with four women from different ages to see how gender roles are transferred through fairy tales. In the second place, I conducted and interview with specialist Melek Özlem Sezer to see the relation between gender, the genre of fairy tale and importance of the narrator. For this expert interview I gathered the names from secondary sources such as books and some children books' authors from the publishing firm which I'm working for.

The interviews were semi- structured interviews which included a list of open-ended questions that were prepared before the interview. Because my questionnaire involved questions related to different periods of interviewee's life such as childhood and marriage I needed to learn how life story interviews were conducted. Therefore Atkinson's book of "The Life Story Interview" (1998) helped me to structure my interview. Atkinson stated that: "In such an interview open- ended questions help draw out the person's feelings about their experiences as well as their deep, reflective thoughts on their life" (Atkinson, 1998, s.40).

\section{Findings}

In this part of the paper, I will try to examine the findings under the categories of importance of women as narrators, generational differences: awareness on gendered issues, representation of women, structural similarities, a new variable: re-writing of fairy tales and functional mutuality.

\section{Importance of Woman as Narrators of Fairy Tales}

One of the hypotheses of this paper is that the narrators of the fairy tales are mostly women. The interviews seem to supportive for this argument. Most of the respondents stated that when they were children the narrators of fairy tales were women around them. When I asked them was there a story telling tradition when they were children one of the responses were:

"Yes, there was a story telling tradition in our home when I was a child. My mother told us. Also we had my grandmother, she has been lived with us since our childhood. She told too." (Banu)

When I asked them whether their fathers told them fairy tales she said:

"He did not. But I remember that if he were at home, while my grandmother was telling he listened her with us." (Banu) 
Additionally, when I asked who told fairy tales mostly another interviewee pointed out: "Old people. I lost both of my grandmothers but we had my aunt's mother in law who was very old. Since we met quite often she told us lots of fairy tales. At home, my mother told too. However she did not have much time for it because she was busy with guests." (Fahriye)

As I asked whether the tellers were mostly women or not she answered that: "Women, of course. I did not remember men were telling. Or I did not hear." (Fahriye)

Furthermore, when I asked another interviewee about story telling tradition in her village she indicated that:

"When I went to the village, my aunt (her father's sister) hadn't marry yet. I remember she looked after me. When she married and left home, my widow aunt (her uncle's wife) started to look after me. She did not leave home when her husband dead, she were living with us. She put me sleep within her arms. Mostly I remember her. She told me lots of fairy tales. I've never forgotten one of them..." (Halide)

As I mentioned before, women as the narrator of the fairy tales play a critical role in transferring function of fairy tales. Since the interpretation and imagination of narrators are decisive, women are responsible for what is transferred to their children through fair tales. As in the expert interview, Melek Özlem Sezer stated that:

"As she/ he provides transferring of fairy tales, the survival of fairy tales up to narrator... Fairy tales give their essential taste by telling because they interact with their environment. In other words, common production is provided which is one of the basic characteristics of fairy tales [through story- telling]."

The importance of narrators in the function of transferring, the symbolic language plays a critical role within that process. As Melek Özlem Sezer mentioned that:

"By constructing complicated labyrinths under the visible surface with the symbols of unconscious, fairy tales operate secondary stories with an extraordinary wit. While all the knots from prenatal period to death, find their meanings on the universal symbols of common unconscious with the contribution of genetic memory, interesting questions are met. Doubled language fairy tales, for example, like Snow White, the symbol of innocence, lost of fairy tales write erotic subtext, in which kissing represents sexual relationship, staying alone in the middle of the forest represents maturation; they hide real story under a pretty context while unconscious percepts it. Thus kissing a dead body does not startle us, or we do not think that dead body was raped. Actually we know that it is not a death and taking the piece of apple off from the throat is needed more (a more shaking move) than kissing."

\section{Generational Difference: Awareness on Gendered Issues}

The interviews showed that there is generational difference on the awareness about gendered characters of fairy tales which can be also related with education level. However education is not one of the variables of the study I do not take such a possible positive correlation into account. Respondents under the age of 50, while one of them stated that when she has noticed the gendered character of the classical fairy tales she preferred to not to tell them to her daughter. When I asked what kind of fairy tales she preferred to tell her child she pointed out that: 
"What kind of fairy tales I told... But I'm sure that I did not try to tell prohibitions through fairy tales. Usually I told stories on adventure like there was a little boat... Goes somewhere to somewhere... Then something happens to it... I tried not to tell those stories such as Snow White or Hansel and Gretel..." (Fahriye)

Additionally when I asked the reason for her not to tell those fairy tales as she mentioned she indicated that:

"Since I know the content of them I did not want to tell such fairy tales. I mean, if I have something to teach, I always prefer to talk directly." (Fahriye)

Furthermore when I asked what those fairy tales teach she said that:

"Those fairy tales are sexists, of course... Snow White, Hansel and Gretel... They tell that if you be a good girl, one day a prince will come and save you. He will give anything that you miss. Because I think they involve that kind of meanings, I did not want to tell, they did not represent the reality. Furthermore, we cannot protect today's children with these fairy tales. We need to be clearer. The relationship between mother, father and child is needed to be clear. I'm saying this by thinking unconscious elements of Snow White. Since sexuality was a taboo, it was hard to discuss about it, they told these fairy tales. They told in indirect ways. Because what the wolf represents is obvious; it represents the dangers of males. However I should tell possible dangers about her/ his sexuality directly. We cannot tell them what happens when they talk strangers in the street by telling Snow White. We need to be clearer, because the world has changed. There are more dangers..." (Fahriye)

Additionally, another respondent pointed out that she needed to change some part of the fairy tales but not because the gendered characteristics of them. Rather she wanted to prevent her son to be afraid of:

"As I mentioned my son was a little bit different. First of all, to prevent my son to be afraid of I changed some part of them like wolf etc. But I do not know whether I'm too optimistic or not, today's educated parents do not need to teach something through fairy tales. I did not try to teach something through them as well. We can communicate directly..." (Halide)

\section{Woman as the Objects of Fear}

Because the existing literature on the relationship between gender and literature mostly covers the Western literature, it was hard to see how Non- western fairy tales reflect women protagonists. As I mentioned in the section of literature review, the representation of women does not change entirely from one fairy tales to another. There are some stereotypes which can be found in most of the fairy tales. In addition, since my interviewees remembered and told traditional and regional fairy tales that stereotyping was easily observed in the fairy tales that we talked about.

In the first interview, my 80 years old respondent told a traditional fairy tales which was called "Bıldik" in which there was a monster and tried to eat B1ldik who is the protagonist of the fairy tale. In the second interview, my 48 years old respondent told another fairy tale with some ethnic components which was about a woman who appears in the evenings and kidnaps children. In the third interview, my 37 years old woman told a very similar fairy tale with the one that the first respondent told, it was about an old woman who wants to eat B1lli, who was the protagonist child of the tale. 


\section{Structural Similarities in Themes of Fairy Tales}

Although I've just conducted five interview, two pairs of women told nearly the same stories. The first interviewee told a fairy tale about chick pea (nohut) children while the second interviewee told another about a bulgur child. In the both of them these children get lost. They tried to reach their mother. According to my third interviewee:

"The reason for the representation of children as derivation of wheat is that to warn children not to far away from their mother."

If they go, they get lost. And as the other fairy tales try to tell, if they go far from their mother, they will be kidnapped by a monster. Furthermore, she also mentioned that she asked about why these children do not grow up, but she did not get any answer from the adults who told the fairy tale. These fairy tales also remind the widely known English fairy tale, "Tom Thumb".

Additionally, again the first interviewee told a fairy tale which she was called "Ekmekçi Bac1" and the fourth interviewee told one which she called "Bit Horoz". Although the characters, objects were not the same, the structure of these two fairy tales was exactly the same. Both of them were finished with the event of kidnapping of a bride by a bird. What is interesting is the first interviewee was 80 years old while the fourth one is 23 . They is no commonality between their life. They were born in different cities, they have totally different cultural backgrounds, and they live in different socio- economic conditions. Then what makes these two women to remember the same fairy tale can be an important question.

Furthermore, the fairy tales which were called B1lli and B1ldik have again similar structures. There was an evil woman in both the fairy tales whose purpose was to eat children. The third interviewee, who told B1lli, indicated that it has some similarities with well known German fairy tale, "Hansel and Gretel". In both fairy tales, there was a little house in the middle of the forest in which a black hearted, evil minded woman lived and her purpose is to eat children.

\section{Re-writers of Fairy Tales}

Mothers from new generation in the interviews stated that they also preferred to read books to their children. Since some of these children books compromise re- writing of classical fairy tales, then these re- writers should be included to narrators. As Melek Özlem Sezer indicated:

"Since fairy tales do not belong only to oral culture any more, fairy tales' writers are needed to be covered. Writers are extremely influential on reconstructing of fairy tales according to current necessities."

\section{Functional Mutuality of Fairy Tales}

Fairy tales have a functional mutuality. When they teach what the society and culture want to children, they remind all of them to adults. Gender roles are one of the components which is transferred through fairy tales. Additionally, as one of the interviewee pointed out that:

Fairy tales may be the way to transfer gender roles. They may force me to be the woman that the society wants. I mean, sometimes I fell that behave in out of the appropriate behaviors is not possible. I mean you go somewhere, somebody needs to serve some tea and you do that while there is no reason to do or anyone except you to do that" (Banu). 


\section{Conclusion and Suggestions for Further Studies}

When I decided to examine fairy tales and their relationship with gender I was planning to do content analysis on fairy tales which were chosen from different cultures or countries. Such a study could give the opportunity to see how gender roles are transferred through similar ways in different cultures. However while I was reading the literature on this theme, I've noticed that talking with women who are both the narrators and the listeners of the fairy tales could serve better for my study. By interviewing women from different generations, I could find answers to more than one question. First of all, I could see how fairy tales affected their life, their self as women; secondly, I could measure their awareness about the embedded meanings within the fairy tales; thirdly, by letting them to tell stories and asking questions which direct them to analyze that fairy tale, I could also analyze the discourse critically that they use. Although I've postponed finding an answer to the third question for another study, I've believed that this paper has found some answers to its questions.

Although fairy tales have functions such as preparing children to sleep or to develop their imaginary, they are needed to be examined with more attention. When we follow the symbols in them and reconstruct the ideological structure we see that the messages which are embedded within them are more surprising than the reality that they create. In the literature, it is stated that fairy tales are seriously affected by narrators' imagination and interpretation. Additionally, since the survival of the fairy tales also depends on social acceptance, narrators play a critical role in transferring function of fairy tales. Gender roles are one of the elements which are transferred through (not only but also) fairy tales. The paper tried to show that women as the narrators of fairy tales are how decisive to transfer gender roles to their children by telling fairy tales. However my opinion here is that not to reject the whole fairy tale tradition. Rather, critical reading of them gives the opportunity to analyze their subtext better.

Furthermore I can suggest some further studies to analyze fairy tales' contribution to constructing gender roles. Since the literature indicated that fairy tales were created for the adults firstly (Zipes, 2006) and they are the only one genre which has lived without any limitation throughout the history (Sezer, 2011), examining earlier versions of fairy tales gives idea about how social reality is created, shaped and changed. Additionally, analyzing illustrations of fairy tales can also provide fruitful explanation for gender representation.

\section{Bibliography}

Atkinson, R. (1993). "The Life Story Interview," in Sage University Papers Series on Qualitative Research Methods, Vol 44. Thousand Oaks, CA: Sage.

Başgöz, İ. (1988). "Masalın Anlatıcısı," in Nuri Taner (edt.). Masal Araştırmaları. İstanbul: Artsan Yayın, pp. 25-31

Boratav, Pertev N. (1992). Zaman Zaman İçinde: Tekerlemeler-Masallar ve Masal ile Tekerleme Üzerine Bir Inceleme, İstanbul: Adam Yayınları

-(1995). 100 Soruda Türk Halk Edebiyatı. İstanbul: Gerçek Yayınevi.

Chodorow, N.J. (1978). The Reproduction of Modering. Berkeley University of California Press.

Goodman, L. (1993). Literature and Gender. London; New York, NY: Routledge in association with the Open University.

Hartland, Edwin S. (2011). The Science of Fairy Tales: An Inquiry into Fairy Mythology. Indo-Europen Publishing. 
İvgin, H. (1988). “Türk Masalları ve Kaynakları,” in Nuri Taner (edt.). Masal Araştırmaları. İstanbul: Artsan Yayın.

Jarrar, O. (2009). "Language Ideology and Fairy Tale: George McDonald's Fairy Tale as a Social Critique of Victorian Norms of Sexuality and Sex Forms," North Wind 28 (2009), 33- 49.

Joosen, V. (2012). Critical and Creative Perspectives on Fairy Tales. Detroit: Wayne State University Press.

Propp, V. (1984). Theory and History of Folklore. Minneapolis: University of Minnesota Press.

Rıfat, M. Rıfat, S. (2008). Vladimir Propp, Masalın Biçimbilimi ve Olağanüstü Masalların Dönüşümleri: Masalın Yapısal ve Tipolojik Incelenmesi. İstanbul: Türkiye İş Bankası Kültür Yayınları, 2008.

Sezer, Melek Ö. (2010). Masallar ve Toplumsal Cinsiyet. İstanbul: Evrensel Basım Yayın.

Wilkinson, Marta, L. (2008). Antigone's Daughters: Gender, Family, and Expression in the Modern Novel. New York: Peter Lang Publishing.

Taner, N. (1988). "Masalın Biçimbilimi ve Vladimir Propp," in Nuri Taner (edt.). Masal Araştırmaları, İstanbul: Artsan Yayın.

Yavuz, Muhsine H. (1997). Masallar ve Eğitimsel İşlevleri. Ankara: Ürün Yayınevi.

Zipes, J. (1999). When Dreams Come True: Classical Fairy Tales and Their Tradition. New York: Routledge, 1999.

(2006). Fairy Tales and The Art of Subversion. New York: Routhledge. 